144 Literatura e Sociedade

\title{
Certo Augusto Boal
}

Cláudia de ArRuda Campos

Universidade de São Paulo

Resumo

Internacionalmente conhecido e respeitado, o diretor de teatro, dramaturgo, teórico, autor, entre outras, das propostas enfeixadas na rubrica Teatro do Oprimido, o múltiplo Boal se unifica no Boal militante, sempre atento às causas políticas, sociais, humanas. Atento e atuante. Este artigo pouco pretende além de repercutir essas qualidades, e, no percurso, somar ao reconhecimento.

\section{Abstract}

Internationally known and respected, the theatre director, playwright, theorist, author, among others, of proposals gathered under the label Theatre of the Oppressed, the multiple Boal unifies himself in the militant Boal, who is always attentive to political, social and human causes. Attentive and active. This essay intends but to reverberate those qualities and, in its course, add to his recognition.
Palavras-chave

Teatro político; Teatro do Oprimido; Teatro de Arena.

\section{Keywords}

Political theatre; Theatre of the Oppressed; Arena Theatre. 
Este texto é, simultaneamente, um testemunho, uma singela homenagem e um grato reconhecimento a Augusto Boal, de quem muitos ensinamentos recebemos, com quem muitos sonhos e projectos partilhamos, com quem muitos fóruns de discussão realizamos. Nele se registram memórias de uma pessoa viva, com ganas de dizer algo através do teatro, nos domínios da intervenção política e social, da terapia, da educação e até do teatro. Mas, à parte tudo isso, Augusto Boal, malgré lui, foi uma personalidade que contagiava o seu entusiasmo a sua força de viver, o seu charme, a sua alegria a sua tolerância, a quem estivesse perto de si. Uma simples conversa com ele transformava-se num happening teatral. ${ }^{1}$

uem fala sobre tema ou autor por demais conhecido e não crê ter novidade a acrescentar, vê-se em situação delicada. Calar talvez fosse a pedida. Perdoe-me, porém, o leitor, se não resisto ao desejo de revisitar algo que me atiça e comove. Assim, tomo o artigo de Luís Aguilar como ponto de partida, ou, mais que isso, como escora, já para rogar condescendência com alguma parcialidade, já para me permitir enveredar um pouco pelo testemunho: o Boal que vi, o Boal que li, e até o Boal de que apenas ouvi falar, mas que incorporei como referência, mesmo quando (parcialidade?) esse falar envolvia crítica.

E, para começar de algum ponto, a imagem presencial mais marcante que me ficou de Augusto Boal está relacionada ao único contato que tive com seu trabalho depois do sufocamento do Teatro de Arena e dos tempos de exílio. Foi num workshop que se iniciava por alguns dos exercícios para atores e não atores, ${ }^{2}$ seguindo-se uma experiência com as técnicas do Teatro fórum. Boal imantava. Minha encorujada timidez e meu medo físico foram nocauteados. O fato é que me envolvi inteiramente nos jogos e, lá pelo fim, me vi jogada ao ombro de um homenzinho das cavernas, muitos anos mais jovem e vários quilos mais magro. Perdão pela reminiscência, que aqui vai sem maiores reflexões...

Na ocasião eu ia já imbuída de algumas críticas que se faziam a propostas do Boal. A principal delas, sobre o chamado teatro invisível. Nessa técnica os circunstantes eram envolvidos em situações criadas pelos atores: uma discussão de bar, uma relação opressiva entre um casal. As pessoas acabavam instadas a entrar no jogo sem saberem, ao menos até o fim da experiência, que se tratava de uma representação. Falou-se em autoritarismo, atitude antidemocrática. Não se justificava 2010.

${ }^{1}$ Disponível em: <http://www.luisaguilar.ca.jornalismo/augustoboal.htm>. Acesso em: 23 dez.

${ }^{2}$ Ver Augusto Boal, Jogos para atores e não-atores, Rio de Janeiro, Civilização Brasileira, 1998. 
arrastar assim as pessoas para a cena. Só se justificaria a participação voluntária, consentida. É bem possível que a minha adesão à crítica tivesse algo a ver com o desagrado que tinha e tenho com certas práticas agressivas realizadas em salas de teatro pretendendo sacudir a acomodação de pessoas bem vestidas que pagavam ingressos para ver um espetáculo do qual, no fim de contas, a agressividade era um atrativo.

O teatro invisível, porém, escapa a esse molde. Teatro de rua, nada tendo de fisicamente agressivo, nem por isso deixou de enfrentar reações irritadas que não eram, por certo, o que se pretendia: fazer romper amarras do hábito, do rito que fazia ver como normais situações e usos que não o são, ou permitia perceber apenas a superfície mascarada das situações de opressão que se encontram no cotidiano.

Opressão. Essa é a palavra que se marcou como a obstinação de Boal. Assim, as propostas que leva à frente a partir dos anos 1960 se reúnem sob um título: Teatro do Oprimido. No interior das várias propostas, uma centelha brechtiana: fissurar as construções dadas como realidades inquestionáveis ou inamovíveis. O Teatro do Oprimido pretende fazer repensar a realidade e estimular sua transformação. O nome - Teatro do Oprimido - já indica que esse repensar/refazer centra-se na concepção de uma realidade dividida entre opressores e oprimidos. Maniqueísmo? Não creio que, salvo à extrema direita, esse rótulo apareça, ao menos sem constrangimento, quando se trata de referência à onipresente opressão.

O Teatro do Oprimido não foi concebido para salas de espetáculos. Tampouco persegue o estético tal como estamos habituados a concebê-lo. Tem, antes, o feitio do fazer social e político e um arsenal de técnicas e exercícios cuja flexibilização acontece em função do tema (tipo de opressão) e das condições específicas de vivência dos grupos participantes. Vai aí, para alguns, um motivo de incômodo com essa prática teatral: isso não é teatro; será política, pedagogia, agitação, para muitos justificável, respeitável, mas teatro, isso não.

De fato, o chamado Teatro do Oprimido não se parece com aquilo que nos acostumamos a ver e sobre o qual alguém especializado pode exercer crítica, com histórias que apreciamos ou não, que nos divertem, comovem ou fazem pensar; desempenhos que admiramos ou não, recursos, uns mais outros menos, elaborados de cenografia, iluminação, som. O teatro já foi definido como arte de representar. Hoje é arte do espetáculo, bom ou mau, e conta já com uma respeitável gama de modalidades, categorias razoavelmente definidas e outras híbridas. Parece difícil conseguir encaixar o Teatro do Oprimido nesse rol. E, no entanto, cada novidade que aparece no circuito comercial tem logo seu selo de cidadania... Neste parágrafo é bem possível que eu esteja glosando o discurso de Boal.

Oprimidos e opressores. A dicotomia nos faz pensar de imediato em oposição política, econômica, envolvendo grupos sociais. Boal vai incluir, porém, as situações de opressão interindividuais. Convidado a apresentar seu trabalho em países com instituições democráticas robustas e distribuição de renda satisfatória, vê-se diante de vivências emocionais carentes de satisfação, resultado de opressões de ordem psicológica. Aliás, quem não ouviu falar de país nórdico, desenvolvido, cheio de oportunidades, mas com taxas soturnas de suicídios? 
O Teatro do Oprimido toma, então, feições terapêuticas: em trabalho coletivo, identificação e enfrentamento dos fantasmas. O procedimento tem, inegavelmente, parentesco muito próximo com o Psicodrama de Moreno, ao qual o diretor brasileiro, indiretamente, não deixa de atribuir créditos. Um novo termo, ou conceito, passa a habitar os escritos de Boal: desejo. Seu livro O arco-íris do desejo ${ }^{3}$ é apresentado como "ainda o Teatro do Oprimido, mas [...] um novo Teatro do Oprimido", ${ }^{4}$ gestado, como dissemos, a partir do contato, na Europa, com oprimidos dessemelhantes dos pobres, imigrantes, trabalhadores explorados, até então alvos únicos ou privilegiados de sua atuação.

Ao introduzir o livro, Boal começa por relembrar uma "saia justa" vivida pelo elenco do Teatro de Arena em uma Liga Camponesa no Nordeste. Um camponês, Virgílio, não compreende e põe em xeque a situação de atores conclamando à luta, mas com fuzis de mentira e sem se integrarem à revolta que se pretendia ver realizada pelos espectadores. Prossegue descrevendo outro entrevero, esse no Peru, quando uma das participantes (espectadora) só se satisfaz quando lhe permitem subir ao palco e mostrar, ela mesma, com fúria, a solução que entendia correta. Até então, a prática era os atores representarem as situações a partir das propostas de solução sugeridas pelos espectadores.

São experiências que disparam um princípio que vai tomar lugar central nas elaborações de Boal. Trata-se de romper a dicotomia entre espectadores e atores. As técnicas dispensam atores especializados. Em seu lugar, os espect-atores. Aquele que sobe ao palco, que constrói ou reconstrói a cena, faz-se protagonista; agente da ação dramática, experimenta-se como sujeito.

Onde fica o estético? Onde fica o artístico? Desde a apresentação do Sistema Coringa, que acompanha a edição de Arena conta Tiradentes, ${ }^{5} \mathrm{o}$ autor-diretor não deixa de se pronunciar a respeito de questões estéticas, nesse texto analisando a trajetória do Arena e fundamentando seu discurso em Brecht. No Teatro do Oprimido $o^{6}$ o discurso retrocede a Aristóteles, passa por Maquiavel, Hegel e Brecht. As observações feitas encaminham-se, sempre, para o argumentativo. A desembocadura é a sustentação das propostas, ou, antes, realizações de Augusto Boal. Livros subsequentes (Técnicas latinoamericanas de teatro popular; Stop c'est magique) dispensam grandes preâmbulos e centram-se na descrição das técnicas e experiências. Mas está lá:

Uma das atrofias mais graves de que sofrem os homens numa sociedade de especialistas é precisamente a atrofia estética.

A atividade estética é imanente a todos os homens, é constante e não pode ser impedida, como a respiração. Só um morto não respira - só os mortos não têm atividade estética. Quando

${ }^{3}$ Augusto Boal, O arco-íris do desejo: o método Boal de teatro e terapia, Rio de Janeiro, Civilização Brasileira, 1996.

${ }^{4}$ Idem, ibidem, p. 17.

${ }^{5}$ Augusto Boal e Gianfrancesco Guarnieri, Arena conta Tiradentes, São Paulo, Livraria Editora Sagarana, 1967.

${ }^{6}$ Augusto Boal, Teatro do oprimido e outras poéticas políticas, Rio de Janeiro, Civilização Brasileira, 1975. 
falamos, escolhemos não apenas as palavras que vamos usar, mas escolhemos também a forma de pronunciá-las. O timbre de voz, o ritmo, a força, a intensidade. As palavras são moduladas esteticamente.

Estética - eis uma palavra que deve ser urgentemente desmistificada. O esteta, etimologicamente, é aquele que sente. E todos nós sentimos, todos nós somos estetas. A comunicação estética nada mais é do que a comunicação sensorial.

A obra de arte é uma forma particular de comunicação estética. É a forma fixa, repetida, reproduzível. Se eu falo, grito, sussurro, estou me comunicando esteticamente sem que por isso esteja produzindo uma obra de arte. Mas quando canto uma canção, quando organizo a emissão de minha voz em determinada maneira (melódica, rítmica etc.) fixa, então estou produzindo uma obra de arte.

O teatro do oprimido ocupa-se da comunicação estética em geral e não de uma de suas formas em particular. Ocupa-se da comunicação sensorial em geral e, também, mas não particularmente, da obra de arte, que é apenas um dos momentos possíveis dessa comunicação. ${ }^{7}$

Para poupar o leitor de outra citação muito longa, retalho trechos de outro escrito:

Para isto serve a Arte: acreditamos que o ato de transformar é transformador [...]

Se agarro com mão firme as palavras que estão no dicionário ou as que correm de boca em boca, se as ordeno do jeito que só eu sei, se as manipulo, alongo, encurto, mudo seu sentido, se transformo palavras, significados e, com elas e eles, escrevo um poema, estarei transformando a realidade destas palavras, estarei criando poesia, e o ato de transformá-las a mim me transforma em poeta - aquele que transforma as palavras.

A mesma coisa acontece com o teatro, quando se trata do Teatro-Fórum, Teatro do Oprimido, quando o espectador se transforma em espect-ator, quando invade a cena e cria imagens ideais do que deseja que venha a ser a realidade, o seu real. O espectador entra em cena e transforma as imagens que vê não ama - ele as transforma em imagens que ama e deseja, imagens de uma sociedade justa, convivial.

Junto com o Boal diretor, propositor de técnicas teatrais, elaborador teórico, militante político, vai o Boal dramaturgo, cuja obra despertou minha admiração ainda na adolescência, quando vi representada por um grupo amador a Revolução na América do Sul, espetáculo surpreendente não apenas pelo conteúdo político explícito e sem pretensão de nuances, mas também pela irreverência da forma teatralista, anárquica, pela deformação expressiva do real mediante recursos da hipérbole e do humor - ácido humor - que se projeta sobre o périplo do operário José da Silva à procura de um... almoço e que acaba morrendo quando por fim enfrenta, solenemente, a marmita básica, com direito a marmelada de sobremesa.

O percurso serve à exposição - sempre jocosa - sobre formas de exploração econômica e política do trabalhador, ou, para ser fiel ao termo usado na peça, do povo, representado ali pelo operário Zé da Silva. Se o Zé pede aumento de salário, é demitido. Se o governo reajusta o salário mínimo, os comerciantes aumentam os

${ }^{7}$ Augusto Boal, Stop, c'est magique, Rio de Janeiro, Civilização Brasileira, 1980, p. 30. 
preços e fica tudo como era dantes. Um projeto de revolução vira uma "revoluçãozinha" pela honestidade, pela "reforma moral". Para o nosso Zé se oferece o ganho de ser "um faminto honesto". ${ }^{8}$ Quando chega a polícia todos escapolem. Resta o Zé com a bandeira na mão. Vai preso, para sua alegria, já que na cadeia, pensa, haverá comida. Alegria passageira. A prisão está cheia demais e o Zé é posto em liberdade. A cena se encerra com uma das canções mais hilárias da peça: A Canção da Liberdade. "Se ser livre é passar fome/ Não quero ser livre não" [...] "Sem comida a liberdade/ É mentira, não é verdade". Ao coro que insiste em dizer "É livre, é livre...". Zé responde com uma "banana": "Tá, que eu sou livre!"

Outra cena que merece lembrança pela efetividade do didatismo e pelo humor é aquela em que o personagem é visitado pelo anjo da guarda, o protetor rigoroso dos interesses das indústrias estrangeiras, empenhado em cobrar royalties sobre cada bem utilizado: a luz, a pasta de dentes, o café, o transporte, até o revólver com que o miserável tenta se suicidar.

De resto, a politicagem, as coligações interesseiras, casuísticas, a demagogia manipuladora, a qual, ao precisar do Povo para seus objetivos eleitorais, até "ressuscita" o Zé, que espera pela morte no oco da floresta para evitar as despesas com enterro.

As Aventuras do Tio Patinhas mantém a mesma formulação didática, sustentada na farsa e na caricatura. O tema agora combina imperialismo e repressão. $\mathrm{O}$ levante da população revoltada é tratado como invasão de extraterrestres. A vitória dos repressores só se alcança pela intervenção de super-heróis dos quadrinhos americanos.

A peça tem uma primeira datação, de 1968, de modo que a relação revolta/ repressão tem como referência os movimentos estudantis que explodem naquele ano. Mas a peça é reelaborada nos anos 1980 e tem a nova data de dezembro de 1983. Se o entrecho básico é o mesmo, assim como as questões políticas que sustentam o tema, o texto recebe recheios que extrapolam o período 1968 e expandem o discurso político. É o caso, por exemplo, de uma palestra sobre mais-valia por ninguém menos que a "Doutora Bertha Dunkell, née Schwarz". Trata-se, como se sabe, do pseudônimo-molecagem com que Roberto Schwarz, a partir do exílio, publicava seus artigos no Pasquim.

Em 1978 estreia em São Paulo a única peça de Augusto Boal que renuncia ao estilo farsesco. Murro em ponta de faca é um texto sobre o exílio e não há graça nenhuma no desgarramento dos exilados, nos fantasmas dos mortos e dos mutilados física ou moralmente. Boal escreve um drama cujos personagens são um grupo de exilados que a partir do primeiro porto, no Chile, peregrinará por outros países, tocados pela situação de instabilidade política na América Latina, pela indisposição de governos europeus em relação aos exilados, os quais vão girando também sobre o eixo de suas nostalgias, da restrição de suas possibilidades de agirem politicamente, da impossibilidade de traçar metas para um futuro, do esgarçamento das relações interpessoais.

${ }^{8}$ Cena 4, cujo título é: "Como vedes, tornou-se inadiável a necessidade de uma revoluçãozinha" (p. 54-59). 
Uma das contribuições mais interessantes de Boal ao Teatro de Arena, no início dos anos 1960, consistiu no que ele chamou de "nacionalização dos clássicos". Menos ou mais do que nacionalização, operava-se um processo de releitura de clássicos de modo a acentuar aquilo que nos textos poderia falar sobre as situações atuais de opressão e reação. Assim se deu a montagem de A mandrágora, de Maquiavel; O noviço, de Martins Pena; O melhor juiz, o rei, de Lope de Vega; Tartufo, de Molière; $O$ inspetor geral, de Gogol. Os textos sofreram maior ou menor intervenção conforme as necessidades de tema e momento. Se em $O$ melhor juiz, o rei as alterações foram significativas, Tartufo, como conta Boal, "foi encenada sem que se lhe alterasse um alexandrino". "Na época em que o texto foi montado" - prossegue Boal - "a hipocrisia religiosa era profundamente utilizada pelos tartufos conterrâneos, que, em nome de Deus, da Pátria, da Família, da Moral, da Liberdade, etc., marchavam pelas ruas exigindo castigos divinos e militares para os ímpios".

Já no exílio, Boal retoma essa prática, mostrando maior liberdade em relação aos textos originais, ao escrever As mulheres de Atenas e A tempestade. E detenho-me um pouco mais nesta última porque ela me diverte muito, até pelo desabrido da linguagem, na qual o palavrão tem lugar tão acertado quanto nas arquibancadas do nosso bendito futebol.

O original de Shakespeare deu origem a diversas versões e reinterpretações. Para o que nos interessa, melhor restringir o espectro àquelas mais abertamente políticas. E isso apenas para termos uma ideia de quão distintas perspectivas a peça permitiu. A mais antiga que conheço é a de Ernest Renan. ${ }^{9}$ Escrito alguns anos após os acontecimentos da Comuna de Paris, o drama parece ter entre suas metas a de propor uma espécie de vacina contra os assaltos da barbárie, ou de tranquilizar as classes dominantes quanto ao risco, para o autor relativo, representado pelas classes populares. Caliban, o bruto e bêbado, trazido para o mundo civilizado, acaba por ir-se instruindo e por entender-se como cidadão. Lidera uma revolta, mas os cortesãos reunidos sob a batuta de Próspero entendem que aquele líder não oferece maior perigo: apostam - e acertam - nas armas da assimilação e da conciliação.

Saltando no tempo, no espaço e no espectro ideológico, convoco o martinicano Aimé Césaire que, em Une tempête ${ }^{10}$ reafirma seu olhar empenhado sobre o mundo negro e as questões da colonização. Se na obra de Shakespeare todo protagonismo cabia a Próspero, o exilado duque de Milão, Césaire muda a chave, dando a palavra central ao escravo Caliban, aquele que, tendo sido senhor da ilha e de seus segredos, tudo perde sob o ferrete do colonizador, incluindo (quase) a identidade. Se há uma tônica sobre a questão da identidade, a isso não se resume a peça, que põe em debate formas divergentes de se pretender a libertação: a via conciliadora, representada por Ariel, o qual acredita até mesmo em uma recuperação moral do dominador; a via radical representada por Caliban. ${ }^{11}$

\footnotetext{
${ }^{9}$ Ernest Renan, "Caliban", in Drames philosophiques, Paris, Calmann-Lévy Éditeurs, s. d.

${ }^{10}$ Aimé Césaire, Une tempête, Paris, Seuil, 1969.

11 Há vestígios na peça que permitem remeter parcialmente ao(s) movimento(s) negro(s) nos Estados Unidos, anos 1960.
} 
Enquadrada em um esquema de psicodrama, a peça do escritor martinicano caminha para a ruptura de toda ideologia imposta pelo colonizador, o qual, diante do desmascaramento a que o expõe o colonizado, assume sua verdade mais crua, declinando de toda pretensa capa de "civilização". A resposta será a violência.

A versão farsesca de Augusto Boal não teve, ao que tudo indica, qualquer inspiração nas leituras ficcionais de A tempestade. Na publicação, ${ }^{12}$ Boal dedica a peça ao poeta cubano Roberto Fernandez Retamar, que, escreve o autor, "foi quem me deu a idéia e o estímulo". O ponto de referência é aqui o ensaio Caliban, de Retamar. ${ }^{13} \mathrm{O}$ cubano recupera leituras do drama shakespeariano desde 1878 (Renan) a meados do século XX, leituras nas quais permanece uma visão pouco mais, pouco menos favorável a Próspero. No mínimo um tirano ilustrado. O eixo do raciocínio de Retamar encontra-se na proposta que faz, explicitamente, de olharmos $A$ tempestade - e a realidade - do ponto de vista de Caliban e, com ele, identificar quem é Próspero: o inimigo. A Revolução, para Retamar, é Caliban vitorioso.

É preciso explicitar que o ensaio do escritor cubano surgiu como uma defesa da Revolução Cubana à vista de reação circunstancial de intelectuais, alguns latino-americanos, questionando métodos repressivos contra escritores que exerceram seu direito de crítica dentro da Revolução. ${ }^{14} \mathrm{O}$ episódio, como era de esperar, foi largamente explorado pela imprensa capitalista. Não à toa, Retamar empenha-se em caracterizar/discutir o personagem Ariel, o outro escravo de Próspero, aéreo e servil, como representação dos intelectuais da mesma ilha de Caliban, aos quais cabe optar entre servir medrosamente a Próspero ou unir-se a Caliban na luta revolucionária.

Trato de fazer essa explicitação para dizer que a peça de Boal bebe a ideia de Próspero dominante/opressor, Caliban oprimido/explorado, mas não guarda outras proximidades com os endereços de Retamar. Tem até mais parentescos com o texto de Césaire, eliminando-se, entretanto, todo laivo de solenidade. Desde Revolução na América do Sul, salvo engano de avaliação, Boal não produzia nada tão desbragadamente hilário. E desde Zumbi e Tiradentes, nada que fosse tão atento à questão do mau destino de alianças indevidas.

Em A tempestade, a única figura tratada com (relativo) respeito é Caliban, como acontecera com o herói Tiradentes na peça de 1967. É o espoliado de sua terra e a quem tentam abafar a própria identidade, o escravo que serve por não ter meios de escapar ao jugo, mas que se revolta, ao contrário do trêfego Ariel que pode até queixar-se pelo adiamento de sua prometida liberdade, mas não deixa de servir gostosamente:

ARIEL - Ai, ai, ai, ai, ai! Salve, Mestre! Aqui estou para cumprir todos os seus desejos, todos! Ordena assim será feito! Se quiseres voarei pelos ares, mergulharei no fogo, cavalgarei as nuvens de cachinhos brancos, ou me perderei no profundo mar azul. Ordena, mestre, e assim será!

${ }^{12}$ Augusto Boal, A tempestade, Lisboa, Plátano, 1977.

${ }^{13}$ Roberto Fernandez Retamar, "Caliban", in Caliban e outros ensaios, São Paulo, Busca Vida, 1988 (o ensaio original foi publicado em 1971 na revista Casa de Las Americas).

${ }^{14}$ A carta aberta a Fidel Castro deveu-se à detenção do poeta Herberto Padilla. 
O bom retrato das disposições de Próspero em relação a esse servo aparece, por certo, na peça de Boal. Mas para não parecer que se exagera, vamos mesmo a Shakespeare:

Próspero - Que! Zangado? Que podes desejar?

Ariel - A liberdade.

Próspero - Antes do tempo certo? Nunca!

Ariel - Lembra-te que te prestei serviços importantes

Nunca menti, não descuidei de nada,

Nem me mostrei queixoso ou rabugento.

Prometeste abater-me um ano inteiro.

Próspero - Pareces esquecido do tormento de que te libertei. [...]

Caso venhas a murmurar de novo,

fendo um carvalho e como cunha te comprimo dentro

de seu nodoso corpo, até que tenhas

ululado durante doze invernos

Ariel - Perdão, mestre; mas hei de conformar-me

a quanto me ordenares... ${ }^{15}$

Consciente da exploração exercida pelo duque sobre os habitantes da ilha, Caliban quer agir. À falta de outros companheiros, atrai o feroz Trínculo, espécie de capataz, a quem Próspero incumbe das ações de chicote e força bruta. Além dele, Sebastião, marujo bêbado que se desgarra pela ilha depois que ali naufraga o rei de Nápoles e comitiva. Próspero os envolve com doçuras e promessas de vinho e status. Ruim aliança. A revolta vira fumaça.

Para ir rapidamente ao desfecho, digamos que assim como na peça de Shakespeare, reinará, plena, a conciliação... mas entre os poderosos. Próspero perdoa o irmão, Antonio, que o mandara para a morte certa; ao rei que a Antonio se acumpliciara. Casa sua inocente Miranda com o filho do rei. E distribui os negócios. Esta última parte concebida para essa versão: uma grande sociedade comercial com direito ao exercício do contrabando, da repressão mais dura para fazer os nativos trabalharem. Como reza a última canção:

\footnotetext{
Não se pode confiar

em gente tão singular;

todos se juntam no final

volta tudo a ser igual
}

Na apresentação de Revolução na América do Sul, escreve Boal:

Pelo visto, a peça não contém nenhum personagem positivo. Mas será necessário? O negativo já não contém em si o seu oposto? Se o Serviço de Trânsito exibe fotografia de desastre, precisará também exibir trevos elegantemente retorcidos sobre os quais deslizam maciamente veículos recém-importados em velocidade moderada? O desastre basta como advertência.

Eu quis apenas fotografar o desastre.

${ }^{15}$ William Shakespeare, "A tempestade", in A tempestade e A comédia dos erros, trad. Carlos Alberto Nunes, Rio de janeiro, Ediouro, s. d. (reproduz edição de 1954, da editora Melhoramentos.) 
Embora tratado com respeito, o Caliban de Boal termina como vítima, impossibilitado de escapar à opressão. Foto do desastre. Mas não sem expressar, em prosa e verso, a consciência da injustiça e da necessidade de reverter a dominação.

E aqui aproveito a deixa para falar de uma faceta que me parece pouco examinada: O Boal poeta, que compõe deliciosas canções, com ou sem a aguda verve humorística que em geral o caracteriza. Permitam-me citar parte de uma das canções de A tempestade, a "Canção da identidade":

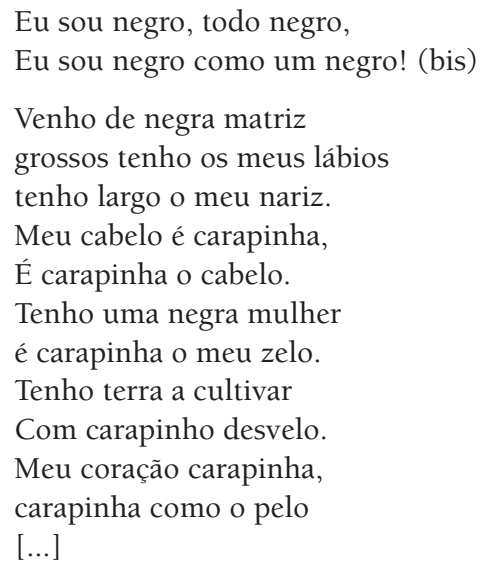

Outras haveria a citar, desde Revolução na América do Sul, da qual já destacamos a "Canção da liberdade", mas não vamos sobrecarregar este texto. Fica a chamada.

As mulheres de Atenas, bastante conhecida pela música de Chico Buarque, combina, com disposição contestatória, Lisístrata e Assembleia de mulheres, de Aristófanes. Também aqui há uma dedicatória, datada de Buenos Aires, 1976:

Esta peça é dedicada a todos os movimentos de libertação feminina e a todas as feministas que tanto me ajudaram a escrevê-la com os seus livros, as suas pesquisas, os seus exemplos e as suas vidas.

O autor estampa, ainda, um preâmbulo acerca de ser "uma peça sobre mulheres escrita por um homem". Necessário cuidado, mas talvez coubesse outro mais, sobre as dificuldades de se escrever sobre ou a partir das reivindicações femininas, resultado de opressões específicas que se sobrepõem a outras que afetam ao conjunto dos humanos oprimidos. Mesmo nos escritos teóricos nem sempre o discurso acerta teor ou tom.

A situação, na primeira parte da peça, é aquela em que as mulheres de Atenas, fartas do abandono, decidem fazer a greve do sexo como forma de pressão para pôr fim à guerra entre Atenas e Esparta e são vitoriosas. A sequência, menos engraçada, seguirá pela discussão dos papéis masculino e feminino, pelo discurso da igualdade social em propostas que, insuficientemente pensadas, redundam em trapalhadas, e a peça acaba com, digamos, alguma pressa no discurso das reivindicações femininas ou não. No discurso: 
Lisa - ... Fizemos muito, mas ainda falta, falta muito! Temos que compreender que não nos podemos liberar sozinhas! Não basta libertar um escravo: é preciso acabar com a escravidão! Temos que ser liberadoras!

As mulheres-atrizes exclamam suas reivindicações (creches, divisão de tarefas domésticas, lavanderias e cozinhas do Estado...) e estimulam as espectadoras a apresentar as suas, que deverão ser repetidas em voz alta.

Boal não é simplista a ponto de dar à peça um final róseo. Dois grupos, misturando homens e mulheres, terminam em posição de enfrentamento. E Lisa diz sua palavra final:

Senhores espectadores, este espetáculo termina aqui. Não lhe podemos dar nenhum final, porque a luta acaba de começar. Boa noite.

Economizo a canção final. Ela não vale a peça.

Voltemos ao Boal diretor/dramaturgo do Teatro de Arena, para reencontrar as peças em que se tomam episódios da história do Brasil para falar, por extensão, de situações atuais: Arena conta Zumbi e Arena conta Tiradentes, coautoria com Gianfrancesco Guarnieri.

Nelas se assume o gesto de narrar, mais claramente na segunda, em que a figura do Coringa introduz a cenas. Extremando a desvinculação ator-personagem, os atores se revezam nos diversos papéis. Os recursos teatralistas de que se lança mão pretendem servir ao objetivo de compor espetáculos que suscitem antes a reflexão que o envolvimento do espectador. Verdade é que, mercê de questões conjunturais, as peças, especialmente Zumbi, acabem por incidir no incitamento a adesão mais emocional que intelectual ao contingente revolucionário do conflito. Algo justificável no contexto político do país, ainda que parte da crítica censure, por isso, os espetáculos.

São histórias elaboradas, criações ficcionais, mas com base em pesquisa. Como reza a canção que abre Arena conta Zumbi, de tudo usou-se um pouco: os autores lançam mão de materiais diversos para compor as peças. No caso de Zumbi, o argumento básico é fornecido por um romance, Ganga Zumba, de João Felício dos Santos. Padre Antonio Vieira e Pero Vaz de Caminha transformam-se em autores cômicos involuntários pelo gesto de se transcreverem seus textos em contextos propícios ao efeito pretendido. Textos jornalísticos e discursos oficiais, além de poemas, são outros entre os vários materiais utilizados. Considerando-se as duas peças, vemos que a criação do Arena tem forte apoio em registros históricos trabalhados de uma forma inédita na dramaturgia brasileira ou, em plano mais geral, na literatura brasileira.

Em Arena conta Zumbi, o assunto é a saga do quilombo de Palmares, que resistiu por todo um século às investidas de várias expedições militares e paramilitares até sucumbir diante das forças comandadas pelo truculento bandeirante Domingos Jorge Velho.

Se a legenda de Palmares não deixava dúvidas quanto a seu caráter heroico e libertário, o mesmo não se dava com os acontecimentos da Inconfidência mineira, 
assunto de Arena conta Tiradentes. Aqueles eventos, repetidos com loas pela história oficial do Brasil eram para alguns, entre esses os autores da peça, suspeitos de mistificação, levando um olhar crítico a perguntar-se sobre a veracidade dos fatos.

A principal pista quanto às disposições iniciais dos autores está em uma das falas do Coringa:

Quando pensamos escrever a história de Tiradentes, tínhamos a impressão de que Silvério não era tão safado como todo mundo dizia, nem o Alferes tão herói como constava. Depois, estudando, chegamos à conclusão de que Tiradentes foi mais herói ainda do que se diz e Silvério tão safado quanto consta. ${ }^{16}$

Os documentos mais próximos, no tempo, aos fatos daquela conspiração, são os Autos da Devassa, registro do inquérito que concluiu pela culpabilidade dos acusados e pela atribuição de culpa maior ao alferes Joaquim José da Silva Xavier, fazendo-o objeto da punição exemplar. Tais documentos por certo devem ser tomados com alguma reserva. Trata-se, no fim de contas, de documentos oficiais do colonizador. O fato, porém, é que nos mostram o alferes assumindo toda a culpa que lhe é atribuída, nos interrogatórios, por alguns de seus companheiros da véspera. Também dali se podem retirar, por exemplo, as evasivas cheias de pretensão de um Gonzaga ou a atitude pusilânime de um Alvarenga que, para livrar-se, denuncia a própria mulher.

E creio que essas observações bastem para ilustrar o esforço do Arena de construir história a partir da história. Como já se disse, porém, não há um mero registro de fatos via documentação. Há criação. Como afirma Boal em um dos textos agregados à edição da peça, "muitas [...] cenas foram escritas com base em documentos da época; porém desses documentos extraiu-se uma fábula que se pretende autônoma". ${ }^{17}$

A afirmação integra passagem em que se expõe uma das "questões preliminares" que a peça propõe. Devolvo a palavra ao autor: "pretende-se do fato sucedido extrair um esquema analógico aplicável a situações semelhantes [...] só se modificam os fatos conhecidos na medida em que mantê-los significaria perda de analogia".

Como apregoa a canção introdutória de Arena conta Zumbi, "de tudo usou-se um pouco/mas de forma que servira/ a mostrar nos dias de hoje/ quem está com a verdade/ quem está com a mentira". ${ }^{18} \mathrm{E}$ aqui já vamos entrando no segundo capítulo desta história que venho contar da forma pela qual a testemunhei.

Num segundo nível, além de contar sucessos do passado, o Arena conta a história próxima à criação daqueles musicais, o Brasil anos 1960, do ponto de vista das esquerdas, ou das chamadas forças progressistas, que procuram elaborar aná-

\footnotetext{
${ }^{16}$ Boal e Guarnieri, Arena conta Tiradentes, op. cit., p. 126.

${ }^{17}$ Augusto Boal, "Tiradentes: questões preliminares", in Augusto Boal e Gianfrancesco Guarnieri, Arena conta Tiradentes, São Paulo, Livraria Editora Sagarana, 1967, p. 45.

${ }^{18}$ Augusto Boal e Gianfrancesco Guarnieri, "Arena conta Zumbi", Revista de Teatro da SBAT, Rio de janeiro, n. 378, nov.-dez. 1970.
} 
lises das falhas que teriam favorecido a vitória dos militares e a instauração da ditadura no país.

Um esquema básico subjaz ao discurso político do Arena sobre a derrota das forças populares, que se mostravam em ebulição nos anos que antecedem o golpe militar: o grupo de esquerda hegemônica, no caso o PCB, seria o maior responsável pelo desastre por conduzir o movimento pré-1964 à armadilha de alianças enganosas com uma pretensa burguesia nacional, que teria, segundo aquele partido, interesses contraditórios com o imperialismo americano. Confiando na política de alianças, as forças populares se desarmaram e foi nesse estado de desarmamento e desamparo político que as alcançaram as forças do obscurantismo.

É esse o enredo que, por analogia, se entretece no centro da narrativa dos fatos que envolvem o quilombo de Palmares. A questão aparece especialmente no aproveitamento que se faz da aliança selada entre os negros quilombolas e os brancos comerciantes.

Também a questão de alianças enganosas aparece, agora de forma mais elaborada, no viés pelo qual se analisa o heroísmo e a desgraça de Tiradentes. Aqui, no entanto, a leitura da Inconfidência Mineira permite agregar à análise outro fator fundamental para explicar a derrota da esquerda em 1964: a ausência do povo no movimento que se pretendia revolucionário. Como explica o Coringa:

\footnotetext{
se é verdade que muitas revoluções burguesas foram feitas pelo povo, também é verdade que, nesta, o povo estava ausente, e mais do que ausente, foi afastado, Por isso, cada conjurado ficou sozinho: longe do povo que não desejava, longe do poder que pretendia derrubar.

Sozinho, cada um pensava na sua prosperidade individual; sozinho, cada um pensou depois na sua salvação. Menos Tiradentes - este queria estar junto - mas escolheu mal com quem.
}

Se esse segundo nível nos remete especialmente à história do golpe de 1964, há nele um terceiro nível implicado e que não se revela em uma ou outra fala, mas no conjunto das opções de composição, dos materiais selecionados e da forma de concebê-los cenicamente. Com isso, temos o terceiro capítulo dessa história do Brasil versão Teatro de Arena: uma história perfeitamente contemporânea aos musicais, aquela que representa uma vivência de esquerda sombreada pela derrota recente e pela repressão, mas aplicada em reagrupar-se e tentar reverter a situação.

$\mathrm{Na}$ análise que fiz das peças, ${ }^{19}$ parece-me ver certa homologia entre as opções dramáticas e o momento vivido pela esquerda que se desprendeu do PCB e de sua linha moderada. Entre outros aspectos que sugerem tal homologia, temos em Zumbi a tradução do reagrupamento ainda desordenado de forças que então se processa pelo revezamento anárquico de papéis, pela movimentação frenética que se debate em todas as direções e em nenhuma definidamente, a não ser aquela onde se defrontam, se reconhecem e se acumpliciam atores e público. Derrubam-se as paredes invisíveis entre palco e plateia, num convite à participação comum em

${ }^{19}$ Cláudia de A. Campos, Zumbi, Tiradentes (e outras histórias contadas pelo Teatro de Arena de São Paulo), São Paulo, Perspectiva/Edusp, 1988. 
sentimentos de revolta e esperança, meia metáfora da derrubada de outras paredes que cerceiam a ação.

O sentido da crise e da rebeldia estende-se ao atrito contra os limites do teatro. A fábula, frágil composição em torno de um estímulo musical, ameaça dissolver-se em um roteiro básico sobre o qual se podem realizar improvisos. Os significados brotam menos do texto que de sentimentos e ideias suscitados pelas vivências comuns de autores, atores e público.

O Teatro de Arena congrega, desde os anos 1950, um público jovem, participante, cujos anseios são, no geral, conhecidos e compartilhados pelo Arena. Teatro e público viviam ideológica e até geograficamente próximos, nas cercanias da Consolação, participando do mesmo universo social e cultural. O elenco do Arena e seu público haviam participado do florescimento cultural e ideológico do país no início dos anos 1960. Até a proposta mais desenvolvida de uma arte popular, o CPC nasce entre os integrantes daquele teatro. O elenco do Arena e seu público foram, em maior ou menor grau, afrontados pelos acontecimentos de 1964.

Em Zumbi, a excessiva cumplicidade entre o Arena e seu público é responsável por alguns dos impasses na estruturação do espetáculo, que levam a mostrar a luta não como um meio, mas como um fim, como algo cujo sentido se encerra em si próprio. Como se lê em Zumbi, "lutar afinal é um modo de crer, é um modo de ter razão de ser". ${ }^{20}$

Por outro lado, é responsável por alguns de seus acertos, entre eles na reação que constrói contra a força obscurantista da repressão que ameaça não apenas as atividades políticas, mas toda uma forma de vida, uma cultura moderna e ativa que se engendrara nos anos anteriores.

Se Arena conta Zumbi, de 1965, representa o tempo da rebeldia, de revolta sem propostas claras; Arena conta Tiradentes, em 1967, corresponde a um tempo de organização, de proposta e militância. Se em Zumbi o principal movimento é o de desforra, sublinhando no inimigo os traços mais negativos; em Tiradentes o principal foco incide sobre os derrotados, examinando-se as causas do fracasso que decorreram da própria constituição dos grupos revolucionários e tendo-se o cuidado de mostrar que a derrota podia ter sido evitada. Se em Zumbi pode-se pensar em um amplexo que acolhe, condescendentemente, todos os derrotados; em Tiradentes o que resta de complacência fica contido na figura do alferes e, com ele, na suposição de existência de uma linha revolucionária correta, enquanto os demais participantes do movimento são alvo de crítica impiedosa. Não à toa o herói e os outros inconfidentes habitam convenções dramáticas diferentes. Em relação ao herói quer-se acentuar a identificação; em relação aos demais, o distanciamento.

Em Arena conta Tiradentes, procura-se evitar cuidadosamente a relativa anarquia que se podia verificar no espetáculo anterior. É possível concordar com Sábato Magaldi no sentimento de que o novo espetáculo, padecendo de excessiva racionalização, amputa as possibilidades comunicativas que se apresentaram em

${ }^{20}$ Boal e Guarniere, Arena conta Zumbi, op. cit., p.54 
Zumbi. Agora, resta ao espectador pouca margem de participação nos sentidos do espetáculo. Os autores procuram eliminar toda ambiguidade por meio de recursos que reiteram muitas vezes, variando as formas, a mesma ideia. Cenas por si mesmas expressivas são comentadas pelo coro. O Coringa, professor aplicado, dispõe-se a explicar, demonstrar. Música, figurino, diversos gêneros - teatrais ou não - articulam-se de forma cerrada, de modo a favorecer a transparência da mensagem. Com isso, o tipo de didatismo que conforma o espetáculo é um tanto impositivo, dirigista, sendo o espectador incitado, por todos os meios, a alinhar-se. Afinal, como reza um dos textos proferidos pelo coro: "quem aceita a tirania/bem merece a condição".

É tempo das vanguardas armadas, das ações exemplares. Uma das cenas, o diálogo entre o Coringa e o Garimpeiro, impõe como primeira interpretação a ideia de que ao povo falta cabeça, no sentido de consciência capaz de dar direção à luta. Cabe, portanto, a alguém que se destaca do povo organizar a resistência armada e, mais do que isso, desencadear a luta.

Assim, com a melhor das intenções e com perfeita generosidade, pensavam jovens que aderiram à luta armada contra o regime. Esse foi, da revolta à organização, o processo vivido por boa parte da esquerda brasileira, cujos atos irão marcar os tempos sem sol da ditadura militar. A história dessa gente também é uma história do Brasil e também está contada pelo Teatro de Arena, sob a regência de Augusto Boal.

O recurso a argumento histórico retorna nos anos 1980, com O corsário do rei, peça que conta com a colaboração musical de Edu Lobo, com letras de Chico Buarque, parcerias respeitáveis, para dizer o mínimo. O território colonial mal administrado fica aberto à cobiça e ao oportunismo de quem se avance para explorá-lo. Por que não Duguay Trouin, o corsário a serviço do rei de França? A expedição invade o Rio de Janeiro em 1711.

Os portugueses parecem bem pouco empenhados em enfrentar Duguay Trouin. O governador foge para o interior, a população também se evade, em pânico. Na partida, o corsário deixa atrás de si uma cidade arrasada, e leva uma fortuna que incluiu vultosa quantia a título de resgate, além dos proveitos de saques em igrejas, prédios públicos e particulares. Consta que a pilhagem teria sido mesmo incentivada pelo governo local por lhe faltarem recursos com que pagar todo o montante exigido pelo invasor.

Como nas outras peças baseadas em assunto histórico, o passado serve de paralelo para a leitura do presente. A relação, em algumas passagens, se faz de forma explícita, como na cena em que o governador e o corsário selam acordo entre pares, um "tratado de paz e prosperidade":

\section{GOVERNADOR}

Senhor Duguay Trouin... Sr. Marinheiro... já que estamos entre amigos... porque aqui não há vencedores nem vencidos... vamos falar francamente: nesta terra, mesmo em não se plantando também dá. Peçam tudo o que quiserem, vamos sempre lhes oferecer mais... Afinal, quem é que trabalha, quem é que paga? São os negros! Peçam o que quiserem! Aqui neste Brasil há muito negro. Eles podem trabalhar. 
No final, a cena se transforma em um coquetel contemporâneo, trazendo, de forma natural, para a continuidade no presente, a rapina do país e a exploração dos trabalhadores.

Em plano mais amplo, O corsário do rei aborda didaticamente os males do capitalismo. A história sobre a expedição de Duguay Trouin é uma peça dentro da peça. Alguns personagens, reunidos em um botequim decadente, resolvem representá-la para recepcionar novos invasores que chegam à baía. Trata-se de uma invasão com um aspecto inédito: "comerciantes confessos", mas desarmados. É uma nova fase, em que foram abolidas as pilhagens a ferro e fogo, trocados, esses por papéis, contratos, empréstimos...

Em cena, o arsenal brechtiano que Boal domina desde Revolução na América do Sul. Aliás, em alguns momentos, O corsário do rei chega a lembrar aquela peça, como a instrumentação de um personagem (em um caso Zé da Silva; no outro Duguay Trouin) pelos poderosos. Destaquem-se, como recursos de distanciamento, o gesto de narrar, a comicidade burlesca, as canções que interrompem as falas. Notável o contraste entre a densidade das canções de Chico Buarque e Edu Lobo e o tipo de comicidade da peça.

As últimas experiências dramatúrgicas de Boal envolvem a nacionalização de óperas, a sambópera, a começar pela montagem de uma Carmem na qual os nossos ritmos e instrumentos populares acompanham o desenrolar de uma história em que toreadores dão lugar a soldados, traficante, jogador de futebol. Delas não falo. Não tive ocasião de conhecer. E, talvez, seja dispensável falar mais.

$\mathrm{Na}$ verdade, parece-me ocioso estar escrevendo tudo isso. Trata-se, até onde imagino, de matéria largamente registrada. O leitor certamente conhece bem Augusto Boal, que é referência mais do que destacada no teatro nacional e internacional. Além das peças, das intervenções, oficinas, workshops, dos prêmios recebidos, da indicação para o Nobel da Paz em 2008, da nomeação pela Unesco como embaixador mundial do teatro, em 2009, o autor, entre peças, teoria, crônica, tem cerca de vinte livros publicados em língua pátria, alguns traduzidos em diversas outras línguas (alemão, espanhol, dinamarquês, francês, inglês, finlandês, norueguês, sueco...).

Mas, lembro, este texto pretendia algo de depoimento pessoal. Assim, resta-me dizer que o último Boal que eu vi foi o vereador do Rio de Janeiro, discursando em uma manifestação, na Cinelândia. Que o peso dos nossos escritos não lhe roube nada do ar livre que sempre procurou compartilhar. 